\title{
PENAMBAHAN EKSTRAK KULIT MANGGIS (Garcinia mangostana. L) DENGAN KOMPOSISI BERBEDA SEBAGAI PEWARNA ALAMI DALAM PENGOLAHAN TERASI BUBUK
}

\section{Addition Skin Extract Mangosteen (Garcinia mangostana. L) With Different Compositions For Natural Dyes In Terasi Powder Processing}

\author{
Slamet Riyadi ${ }^{1}$, Arno Wiranata ${ }^{2}$ dan Fitra Mulia Jaya ${ }^{2 *}$ \\ ${ }^{1}$ Dinas Perikanan Kota Palembang \\ ${ }^{2}$ Program Studi Ilmu Perikanan, Fakultas Perikanan Universitas PGRI Palembang \\ *Corresponding author : f_muliajaya@yahoo.com
}

\begin{abstract}
ABSTRAK
Terasi merupakan bumbu tradisional yang banyak disukai oleh masyarakat. Permasalahan penggunaan pewarna buatan terasi diduga dapat diatasi dengan penambahan ekstrak kulit manggis (Garcinia mangostana. L) yang kaya akan anthosianin. Perlakuan pada penelitian ini berupa penambahan Ekstrak Kulit Manggis pada pengolahan terasi dengan berbagai konsentrasi (B/B) yaitu : $0 \%, 2.5 \%, 5 \%, 7.5 \%, 10 \%$ (dari berat bahan baku). Nilai analisa fisik dari hasil terasi bubuk terbaik terdapat pada perlakuan penambahan ekstrak kulit manggis $10 \%$ (W5) dengan nilai lightness 47.61, chroma 27.11 dan hue 50.01. Nilai mutu organoleptik terasi bubuk terbaik terdapat pada perlakuan penambahan ekstrak kulit manggis $10 \%$ (W5) dengan nilai warna $3.76 \%$, penampakan $3.60 \%$, aroma $3.52 \%$, rasa $3.60 \%$. Nilai mutu kimia terasi bubuk terbaik berdasarkan nilai mutu fisik dan organoleptik terbaik adalah kadar air $19.75 \%$, abu $11.14 \%$, protein $40.41 \%$, lemak $2.00 \%$, karbohidrat $26.30 \%$.
\end{abstract}

Kata Kunci : Terasi, Ekstrak Kulit Manggis, Pewarna alami

\begin{abstract}
Terasi is a traditional spice. The problem of using artificial shrimp paste can be overcome by extracting mangosteen peel (Garcinia mangostana. L) which is rich in anthocyanin. The treatment in this study consisted of mangosteen peel extraction in terasi processing with various concentrations $(\mathrm{B} / \mathrm{B})$, treatment: $0 \%, 2.5 \%, 5 \%, 7.5 \%, 10 \%$ (by weight of raw material). The physical analysis value of the best powdered terasi results in granting approval of mangosteen peel extract $10 \%$ (W5) with a mild value of 47.61 , chroma 27.11 and hue 50.01 . Organoleptic quality value of $10 \%$ (W5) with a color value of $3.76 \%$, appearance of $3.60 \%$, aroma of $3.52 \%$, taste of $3.60 \%$. The highest chemical quality value of the shrimp paste powder was $19.75 \%$, ash $11.14 \%$, protein $40.41 \%$, fat $2.00 \%$, content $26.30 \%$.
\end{abstract}

Keywords: shrimp paste, mangosteen peel extract, natural stain 


\section{PENDAHULUAN}

Sektor perikanan di Indonesia mempunyai peluang yang cukup besar karena geografisnya yang berupa kepulauan. Salah satu jenis udang yang dihasilkan di Indonesia yaitu udang rebon. Provinsi Sumatera Selatan, tepatnya desa Sungsang Kecamatan Banyuasin II, Kabupaten Banyuasin, merupakan daerah penangkapan udang yang potensial karena didaerah tersebut terdapat Sungai Sembilang, merupakan perairan estuaria yang memiliki banyak jenis udang, ikan, kepiting dan hewan kecil lainnya. Potensi yang besar ini meningkatkan keinginan para nelayan untuk melakukan aktivitas penangkapan udang. Oleh sebab itu, ada banyak produk pangan tradisional yang berbahan baku udang di desa Sungsang, salah satunya adalah udang Rebon yang bisa diolah menjadi terasi (Sari, 2011).

Terasi merupakan bumbu tradisional yang banyak dikenal dan disukai oleh masyarakat Indonesia. Banyak orang menyukai terasi karena rasa dan aromanya yang khas, terutama untuk meningkatkan selera makan. Namun, terasi yang banyak disukai oleh konsumen yaitu terasi berwarna merah yang terlihat menarik, hal ini yang mendorong produsen menggunakan pewarna buatan dalam proses pembuatan terasi, dengan maraknya penggunaan pewarna makanan yang dilarang terutama pada jajanan pasar membuat para konsumen merasa khawatir terhadap aspek keamanan pangan, oleh sebab itu perlu adanya alternatif penggunaan pewarna alami pada makanan untuk menggantikan pewarnapewarna sintetis yang sudah tidak diizinkan lagi peredarannya, sebaiknya digunakan pewarna alami yang diizinkan pemakaiannya (Wijaya dan Mulyono, 2009).

Salah satu buah yang dapat digunakan untuk pembuatan zat pewarna alami yaitu dari kulit buah Manggis (Garcinia mangostana L.), jika semua kandungan yang terdapat pada kulit buah manggis tersebut diekstraksi, maka akan didapat bahan pewarna alami berupa Anthosianin. Anthosianin merupakan zat pewarna alami yang bersifat polar dan akan larut dengan baik pada pelarutpelarut polar sehingga akan menghasilkan warna merah, ungu dan biru sebagai bahan pewarna alami dalam pembuatan terasi (Indra, 2009 dalam Saraswati dan Astutik, 2011).

\section{METODE PENELITIAN Persiapan}

Bahan baku yang digunakan terdiri dari udang rebon yang didapat dari daerah Sungsang. Bahan pendukung terdiri dari : garam, air, kulit buah manggis dan bahan kimia yang meliputi larutan Etanol $96 \%$.

Alat yang digunakan dalam penelitian ini terdiri dari : alat untuk pengolahan dan alat untuk analisa laboratorium. Alat pengolahan yang digunakan meliputi : mesin blender, alat penggilingan, oven, ayakan plastik, neraca analitik, baskom, talenan. Alat-alat yang digunakan untuk analisa di laboratorium meliputi : kain kasa, cawan porselen, desikator, neraca analitik, oven, tabung kjeldahl, alat destilasi, labu destilasi, tabung kondensor, labu erlenmeyer, muffle furnace, kertas saring, soxhlet, labu lemak, cawan petri, gelas ukur, colour reader CR-10, termometer, penjepit cawan, pipet tetes, tabung reaksi dan alat titrasi. 


\section{Pelaksanaan Penelitian}

Proses pengolahan terasi dengan penambahan ekstrak kulit manggis sebagai pewarna alami ini sebelumnya telah dilakukan penelitian pendahuluan sehingga telah didapat komposisi ekstrak kulit manggis yang tepat pada penambahan pembuatan terasi. pada dasarnya penelitian ini terdiri dari dua tahap yaitu : proses ekstraksi kulit manggis dan proses pengolahan terasi dengan penambahan ekstrak kulit manggis.

\section{Tahap Pertama:}

\section{Proses Ekstrak Kulit Manggis}

Memisahkan kulit manggis dengan isi daging buah. kulit bagian dalam nya saja diambil sementara kulit bagian luar tidak bisa digunakan dikarenakan banyak mengandung getah dan rasa nya pahit. Selanjutnya kulit manggis dipotong menjadi ukuran kecil. kemudian kulit manggis diblender dengan kecepatan nomor 1 selama 5 menit.

Setelah itu hancuran kulit manggis dijemur selama 5 jam dengan suhu $60^{\circ} \mathrm{C}$. Hancuran kulit manggis yang telah kering kemudian dihaluskan kembali dengan blender kecepatan nomor 1 selama 5 menit, yang bertujuan untuk mengecilkan ukuran dari hancuran kulit manggis agar proses ekstraksi berjalan dengan efektif.

Hancuran kulit manggis sebanyak 1000 gram diekstraksi dengan kadar etanol $96 \%$ sebanyak $10 \mathrm{~L}$ dengan metode maserasi selama 5 hari pada suhu ruangan. Selanjutnya disaring kedalam erlenmeyer vakum menggunakan corong dan pompa vakum. Setelah itu kemudian diuapkan dengan menggunakan rottary evaporator dengan suhu $60^{\circ} \mathrm{C}$ selama 30 jam.
Kemudian ekstrak pigmen kulit manggis dalam bentuk gel.

\section{Tahap Kedua:}

\section{Proses Pengolahan Terasi Bubuk}

Udang segar sebanyak $1,5 \mathrm{~kg}$ dicuci sampai bersih, kemudian tiriskan selama 5 menit. Udang ditambahkan garam $10 \%$ dan ekstrak pewarna kulit manggis sesuai dengan metode perlakuan yaitu $0 \%, 2,5 \%$, $5 \%, 7,5 \%, 10 \%$ dari berat bahan baku udang (b/b) dihomogen kan dengan cara diblender.

Jemur udang di bawah sinar matahari selama 5-7 jam dengan suhu $60^{\circ} \mathrm{C}$ hingga menjadi setengah kering. Setelah udang dijemur menjadi setengah kering kemudian ditumbuk. Selanjutnya udang difermentasi selama 7 hari dengan cara diperam kedalam karung plastik, setelah difermentasi diamkan selama beberapa menit. Setelah itu terasi yang sudah siap, dicetak dalam bentuk balok dengan ukuran panjang $8 \mathrm{~cm}$ dan lebar 6 $\mathrm{cm}$ dan diiris tipis $\leq 2 \mathrm{~mm}$ untuk mempercepat proses pengeringan.

Selanjutnya dilakukan pengeringan dengan menggunakan oven pada suhu 150 ${ }^{0} \mathrm{C}$ selama 45 menit dengan cara di aduk dengan menggunakan sendok tiap 5 menit sekali agar pengeringan merata sempurna. Terasi yang telah kering kemudian ditepung dengan menggunakan alat penepung (tipe pin mill). Setelah itu dilakukan pengayakan dengan ukuran ayakan 6 mesh, sehingga didapatkan bubuk terasi yang halus

\section{Rancangan Percobaan}

Penelitian ini menggunakan pola Rancangan Acak Lengkap (RAL) dengan perlakuan konsentrasi kulit manggis 
(Garcinia mangostana L.) yang akan ditambahkan dalam pengolahan terasi bubuk, dalam penelitian ini menggunakan 5 (lima) taraf perlakuan dengan 3 (tiga) kali pengulangan. Komposisi ekstrak kulit manggis yang digunakan yaitu : $0 \%$, $2,5 \%, 5 \%, 7,5 \%, 10 \%$ dari berat bahan baku (b/b).

\section{HASIL DAN PEMBAHASAN}

\section{Analisa Fisik}

Analisa fisik yang dilakukan di dalam penelitian ini adalah pengukuran warna terasi bubuk. Pengukuran warna dilakukan dengan menggunakan alat colour reader CR-10. Alat ini bisa membedakan warna dengan berdasarkan tiga nilai yaitu : lightness $(\mathrm{L})$, chroma $(\mathrm{C})$, dan hue $(\mathrm{H})$.

\section{Lightness (L)}

Nilai lightness merupakan tingkat warna berdasarkan pencampuran dengan unsur warna putih sebagai unsur warna yang memunculkan kesan warna terang dan gelap. Nilai koreksi warna lightness berkisar antara 0 untuk warna gelap (hitam) dan 100 untuk warna terang (putih). Adapun hasil pengukuran nilai rata-rata warna nilai lightness Terasi Bubuk dapat dilihat pada Gambar 1.

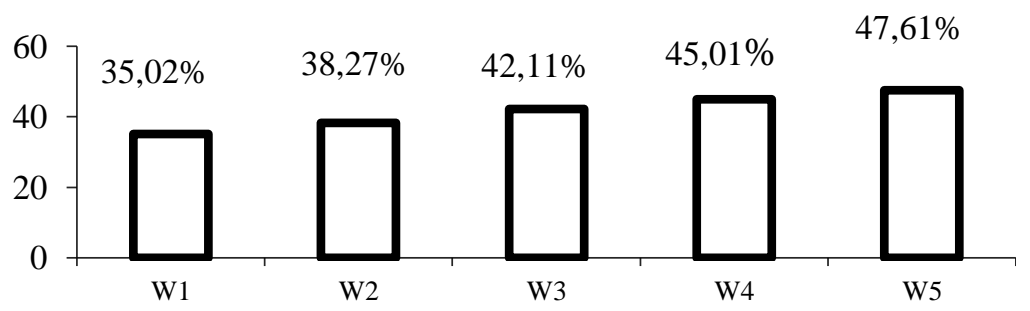

Gambar 1. Nilai rata-rata warna nilai lightness Terasi Bubuk

Pada Diagram diatas, menunjukkan bahwa perlakuan $\mathrm{W}_{5}(10 \%$ ekstrak kulit manggis) berbeda sangat nyata dengan $\mathrm{W}_{4}$ (7.5\% ekstrak kulit manggis), $\mathrm{W}_{3}(5 \%$ ekstrak kulit manggis), $\mathrm{W}_{2}$ (2.5\% ekstrak kulit manggis), $\mathrm{W}_{1}(0 \%$ ekstrak kulit manggis). Nilai rata-rata lightness mengalami peningkatan, sehingga nilai kecerahan menjadi naik. Hal ini dikarenakan warna antosianin dipengaruhi oleh konsentrasi pelarut Etanol, dengan semakin banyaknya konsentrasi pelarut Etanol, maka dapat menyebabkan stabilitas antosianin bertambah yang membuat warna menjadi lebih terang (Farida dan Nisa, 2014).

\section{Chroma}

Chroma merupakan besaran yang digunakan dalamp komponen warna, yang menunjukkan intensitas warna (Winarno, 1991). Chroma adalah tingkatan warna berdasarkan ketajamannya berfungsi untuk mendefinisikan warna suatu produk cenderung mengkilap atau cenderung kusam. Chroma mengikuti presentase yang berkisar dari 0 sampai 100. Semakin tinggi nilai chroma, maka produk tersebut semakin kusam, sedangkan nilai chroma yang semakin rendah maka semakin mengkilap. Nilai rata-rata chroma terasi dengan ekstrak kulit manggis dapat dilihat pada Gambar 2. 


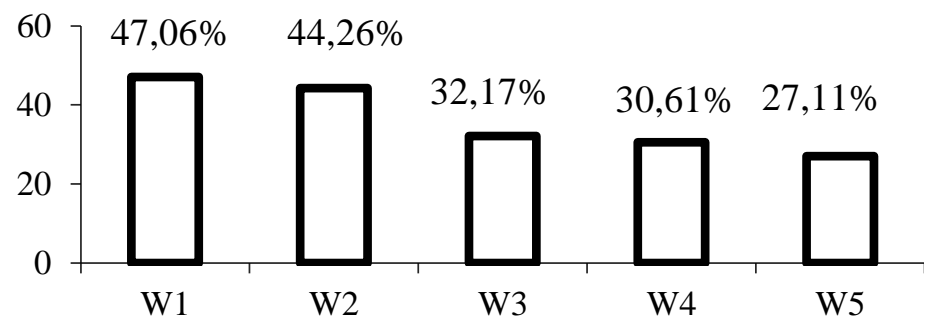

Gambar 2. Nilai rata-rata chroma terasi dengan ekstrak kulit manggis

Pada Diagram diatas, nilai rata - rata warna Chroma cenderung mengalami penurunan dengan semakin tingginya konsentrasi ekstrak kulit manggis yang ditambahkan. Konsentrasi ekstrak kulit manggis berpengaruh terhadap nilai Chroma yang dihasilkan. Hal ini disebabkan semakin banyak nya konsentrasi ekstrak kulit manggis maka akan semakin rendah nilai chroma sehingga warna terasi yang dihasilkan akan semakin cerah (Yuniwati dkk, 2013).
Hue

Nilai Hue merupakan nilai yang mewakili panjang gelombang yang dominan yang akan menentukan apakah warna tersebut merah, hijau atau kuning (Winarno, 1997). Adapun hasil pengukuran nilai rata-rata Hue Terasi dengan ekstrak kulit manggis dapat dilihat pada Gambar 3.

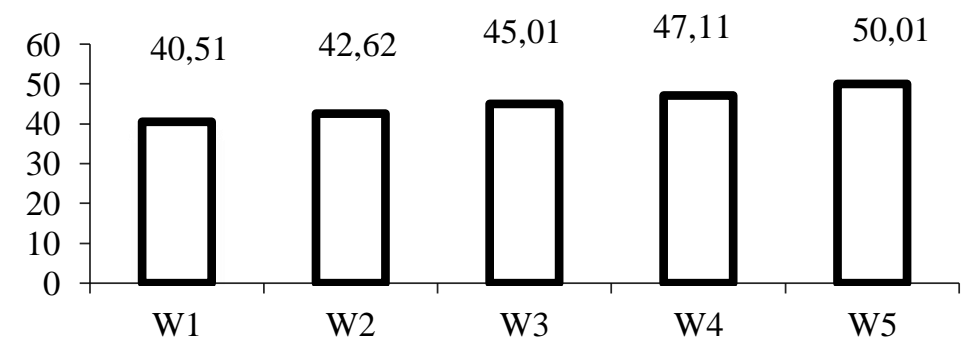

Gambar 3. Nilai rata-rata Hue Terasi dengan ekstrak kulit manggis

Pada Diagram, menunjukkan bahwa perlakuan $\mathrm{W}_{5} \quad(10 \%$ ekstrak kulit manggis) berbeda sangat nyata dengan $\mathrm{W}_{4}$ (7.5\% ekstrak kulit manggis), $\mathrm{W}_{3}(5 \%$ ekstrak kulit manggis), $\mathrm{W}_{2}$ (2.5\% ekstrak kulit manggis), $\mathrm{W}_{1}(0 \%$ ekstrak kulit manggis). Nilai rata-rata warna hue cenderung mengalami peningkatan, hal ini dapat dipahami karena nilai hue tersebut dipengaruhi oleh jumlah antosianin yang terekstrak semakin banyak. Selain itu kisaran rentang nilai hue pada penelitian ini menunjukkan bahwa hasil ektraksi kulit buah manggis berwarna merah dengan di dukung literatur yang menyebutkan bahwa zat warna yang dideteksi dengan sinar tampak berwarna jingga, atau merah adalah antosianidin 3glikosida. Berdasarkan ciri spektrumnya, zat warna dengan panjang gelombang maksimum $18^{0}-54^{0}$ adalah warna merah. Hal ini membuat warna pada terasi udang rebon yang dihasilkan dari ekstrak kulit 
manggis akan menjadi lebih merah (Farida dan Nisa, 2014).

\section{Uji Organolpetik}

Pengujian organoleptik merupakan cara pengujian dengan indera manusia sebagai alat utama untuk pengukuran daya penerimaan terhadap makanan. Sasaran alat indera ditujukan terhadap warna, aroma, penampakan dan rasa.
Warna

Mutu bahan pangan pada umumnya tergantung pada beberapa faktor. Faktor-faktor tersebut antara lain : rasa, tekstur, nilai gizi, mikrobiologi dan warna. Sebelum faktor lain dipertimbangkan, secara visual faktor warna akan tampil lebih dulu (Winarno, 1997). Nilai rata-rata skor organoleptik warna terasi dengan ekstak kulit manggis dapat dilihat pada Gambar 4.

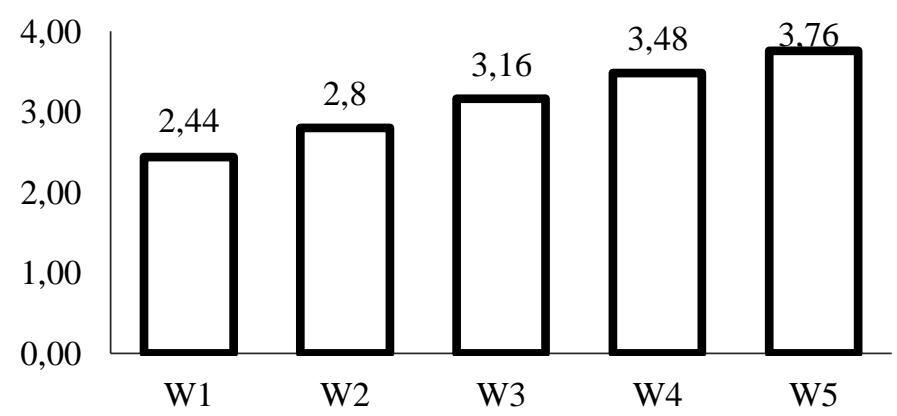

Gambar 4. Nilai rata-rata skor organoleptik warna terasi

Menurut Pareira (2008), kulit buah manggis mengandung dua senyawa alkaloid dan lateks kering, manggis mengandung sejumlah pigmen yang berasal dari dua metabolit, yaitu mangostin dan -mangostin yang jika diekstraksi dapat menghasilkan bahan pewarna alami berupa antosianin yang menghasilkan warna merah, ungu dan biru. Kulit buah mengandung antosianin seperti cyanidin-3-sophoroside dan cyanidin-3-glucoside. Senyawa tersebut yang membuat warna pada terasi lebih menarik, sehingga lebih banya disukai oleh panelis

\section{Aroma}

Aroma lebih banyak berhubungan dengan panca indera pembau. Bau-bauan baru dapat dikenali, bila terbentuk uap danmolekul-molekul komponen bau yang menyentuh silia sel olfaktori. Pada umumnya bau yang diterima oleh hidung dan otak lebih banyak merupakan campuran empat bau utama yaitu harum, asam, tengik dan hangus (Winarno, 1997). Nilai rata-rata skor organoleptik aroma terasi bubuk dapat dilihat pada Gambar 5 .

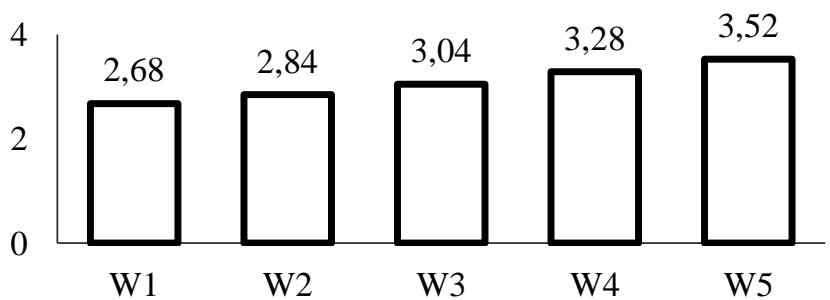

Gambar 5. Nilai rata-rata skor organoleptik aroma terasi bubuk ekstak kulit manggis 
Berdasarkan data diatas dapat diketahui bahwa penambahan ekstrak kulit manggis dapat meningkatkan organoleptik aroma pada terasi, hal ini dikarenakan aroma yang dihasilkan berasal dari senyawa aromatik, yaitu senyawa yang memiliki bau dan aroma yang khas pada kulit manggis seperti kandungan senyawa Fenol, menurut Winarno (2002) aroma dipengaruhi indera penciuman yaitu campuran dari empat macam bau yaitu harum, asam, tengik dan hangus, bau tersebut diterima oleh hidung lalu ditransfer ke otak.

\section{Penampakan}

Penampakan pada terasi dapat dipengaruhi oleh faktor-faktor yang juga mempengaruhi warna dan bentuknya, seperti penggunaan suhu tinggi dan waktu yang lama pada saat pengeringan (Winarno, 1997). Nilai rata-rata skor organoleptik penampakan terasi bubuk dapat dilihat pada Gambar 6.

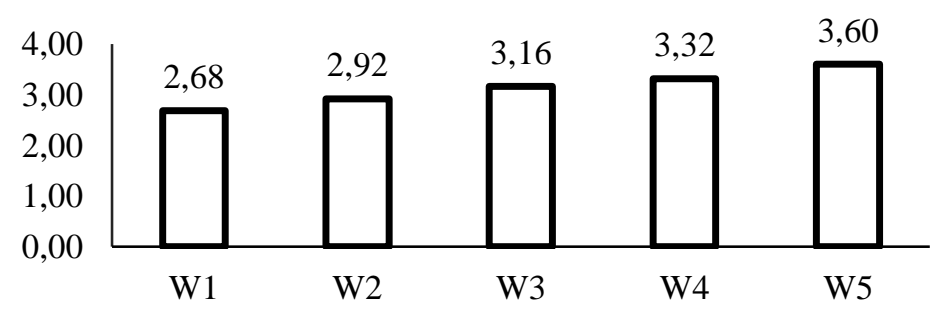

Gambar 6. Nilai rata-rata skor organoleptik warna terasi

Berdasarkan pada uji diatas, penampakan terasi udang rebon dengan penambahan ekstrak kulit manggis menunjukkan bahwa berbeda nyata. Penambahan ekstrak kulit manggis dengan komposisi berbeda menimbulkan perbedaan penampaakan yang dihasilkan pada terasi. Panelis lebih menyukai terasi udang rebon dengan penambahan kulit manggis pada perlakuan $\mathrm{W}_{5}$ (Ekstak kulit manggis $10 \%$ ), karena penampakan terasi yang dihasilkan berwana merah, hal ini disebabkan zat antosianin yang terkandung dalam kulit buah manggis. Semakin banyak penambahan ekstrak kulit manggis yang ditambahkan maka akan semakin jelas penampakan terasi yang dihasilkan oleh ektrak kulit manggis yang memiliki warna kemerahan yang dapat diterima oleh panelis. Warna memegang peranan penting dalam penerimaan makanan oleh konsumen, warna juga memberikan petunjuk mengenai perubahan kimia dalam makanan (Sari dkk, 2009).

Rasa

Rasa merupakan faktor penting untuk menentukan diterima atau tidaknya suatu produk makanan. Walaupun semua parameter normal, tetapi tidak diikuti oleh rasa yang enak maka makanan tersebut tidak akan diterima oleh konsumen. Rasa lebih banyak melibatkan indera pengecap (Winarno, 1997). Walaupun warna, aroma, dan tekstur baik, jika rasanya tidak enak, maka makanan tersebut tidak akan diterima. Oleh karena itu, rasa merupakan faktor penting lainnya dalam keputusan terakhir konsumen untuk menerima atau menolak suatu makanan. Diagram batang nilai rata-rata rasa terasi dengan perlakuan penambahan ekstrak kulit manggis dapat dilihat pada Gambar 7. 


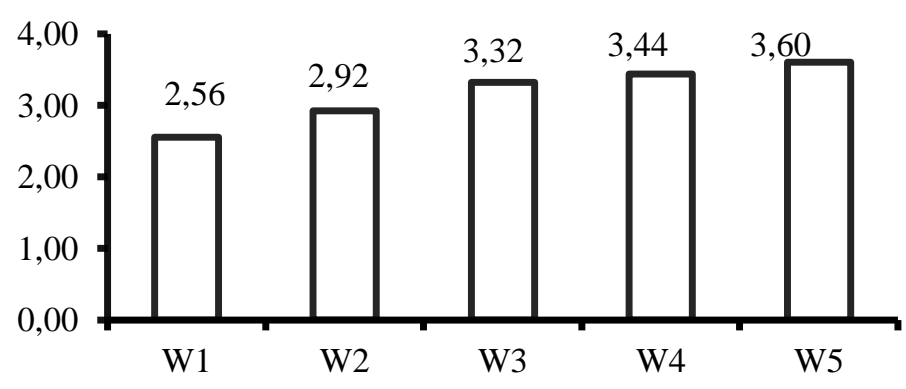

Gambar 7. nilai rata-rata rasa terasi dengan perlakuan penambahan ekstrak kulit manggis

Berdasarkan uji Friedman-Conover pada uji hedonik rasa terasi udang rebon dengan penambahan ekstrak kulit manggis menunjukkan bahwa berbeda nyata. Penambahan ekstrak kulit manggis dengan komposisi berbeda menimbulkan perbedaan rasa yang dihasilkan pada terasi. Hal ini dikarenakan pada kulit buah manggis mengandung anthosianin, pektin, tanin, zat warna hitam, dan zat antibiotik xanthone (Verherj, 1997).

adanya kandungan tanin ini yang dapat menyebabkan rasa dari kulit manggis sehingga menjadi pahit. Akan tetapi senyawa tanin pada umumnya dapat larut dengan pelarut dari polar seperti Etanol sampai semi polar, sehingga hal ini tidak berpengaruh terhadap rasa uji organoleptik penambahan ekstrak kulit manggis terhadap pengolahan terasi (Hernawan dan Setyawan, 2003).

\section{Analisa Kimia}

Analisa kimia dilakukan berdasarkan hasil dari analisa fisik dan analisa organoleptik perlakuan yang terbaik, yaitu terdapat pada perlakuan W5 dengan penambahan $10 \%$ ekstrak kulit manggis dalam pengolahan terasi bubuk, sehingga dilakukan analisa kimia terasi bubuk dengan penambahan ekstrak kulit manggis dapat dilihat pada Tabel 1 sebagai berikut.

Tabel 1. Uji analisa kimia berdasarkan perlakuan yang terbaik.

\begin{tabular}{cccccc}
\hline Perlakuan & $\begin{array}{c}\text { Kadar Air } \\
(\boldsymbol{\%})\end{array}$ & $\begin{array}{c}\text { Kadar } \\
\mathbf{A b u} \\
(\boldsymbol{\%})\end{array}$ & $\begin{array}{c}\text { Kadar } \\
\text { Protein } \\
(\boldsymbol{\%})\end{array}$ & $\begin{array}{c}\text { Kadar } \\
\text { Lemak } \\
(\boldsymbol{\%})\end{array}$ & $\begin{array}{c}\text { Kadar } \\
\text { Karbohidrat } \\
(\boldsymbol{\%})\end{array}$ \\
\hline \begin{tabular}{l} 
W5: $\begin{array}{c}\text { 10\% ekstrak kulit } \\
\text { manggis }\end{array}$ \\
\hline
\end{tabular} & 19,75 & 11,14 & 40,41 & 2,0 & 26,30 \\
\hline
\end{tabular}

\section{SIMPULAN}

Berdasarkan nilai analisa fisik, nilai mutu organoleptik dan nilai mutu kimia terasi bubuk berdasarkan nilai mutu fisik dan organoleptik dengan perlakuan penambahan ekstrak kulit manggis terbaik adalah pada perlakukan W5 dengan komposisi pemnambahan ekstrak kulit manggis sebnyak $10 \%$.

\section{SARAN}

Berdasarkan hasil penelitian yang telah dilakukan, perlu dilakukan penelitian lanjutan mengenai umur simpan terasi dengan ekstrak kulit manggis yang meliputi aspek mikrobiologis dan teknik pengemasan yang tepat. 


\section{DAFTAR PUSTAKA}

Farida, R., dan Nisa, F. C., 2014. Ekstraksi Antosianin Limbah Kulit Manggis Metode Microwave Assisted Extraction (Lama Ekstraksi dan Rasio Bahan Pelarut). Jurnal Pangan dan Agroindustri 3 (2) : 362-373.

Hernawan, U.E. dan A.D Setyawan. 2003. Ellagitanin; Biosintesis, Isolasi, dan Aktivitas Biologi. J. Biofarmasi 1: 25-38.

Pareira, Macklin. 2008. Pemanfaatan Kulit Buah Manggis Untuk Dijadikan Pewarna Alami. http://www.macklin.onbuk.com/20

08/12/pemanfaatan-kulit-buah manggis-untuk-dijadikan-bahanpewarna-alami/. Diakses pada 17 Januari 2014.

Saraswati, N.D., dan Astutik, S.E. 2011.

Ekstraksi Zat Warna Alami Dari Kulit Manggis Serta Uji Stabilitasnya 2 (1): $1-8$.

Sari, N. I., Edison, dan Sukirno M. 2009. Kajian Tingkat Penerimaan Konsumen terhadap Produk Terasi Ikan dengan Penambahan Ekstrak Rosela. Berkala Perikanan Terubuk.37 (2): 91-103.
Sari, D. I., 2011. Karakteristik Terasi Jembret Instan dengan Lama Waktu Pengeringan yang Berbeda. Skripsi S1. Fakultas Pertanian. Universitas Sriwijaya. Indralaya (tidak dipublikasikan).

Verherj, E. W. M. dan R. E. Coronel. 1997. Proses II. Sumber Daya Nabati Asia Tenggara Buah-buahan yang Dapat Dimakan. Gramedia. Jakarta.

Wijaya, C. H. Dan N. Mulyono. 2009. Bahan Tambahan Pangan Pewarna. Cetakan Pertama. Penerbit Institut Pertanian Bogor. Bogor.

Winarno, F.G. 1991. Kimia Pangan dan Gizi. Gramedia . Jakarta.

Winarno, F. G. 1997. Kimia Pangan dan Gizi. Gramedia. Jakarta.

Winarno, F. G. 2002. Kimia Pangan dan Gizi. Gramedia. Jakarta

Yuniwati, M., Ovitasari, F., Wulandari, D. 2013. Pengambilan Zat Warna Alami Anthosianin Dari Ekstrak Kulit Manggis. Jurnal Teknosains Pangan 5 (2) : 1979-8415. 